\title{
PENGARUH WISATAWAN NEGARA CHINA TERHADAP PRODUK DOMESTIK BRUTO INDONESIA TAHUN 2007-2016
}

\author{
Naufal Sulistyawan
}

\begin{abstract}
Abstrak
Pariwisata merupakan salah satu penopang perekonomian di Indonesia, ini dikarenakan pariwisata menjadi urutan nomor 4 untuk ranking devisa pada tahun 20142015. Pada tahun 2016 Indonesia memiliki 11.519.275 wisatawan asing dari berbagai macam negara. Jumlah tersebut mengalami peningkatan sebesar $13 \%$ dari tahun sebelumnya yaitu 10.230.775.China menjadi salah satu negara yang menjadi penyumbang wisatawan terbanyak pada tahun 2016. Tujuan dari penelitian ini yaitu untuk menguji apakah wisatawan china berpengaruh terhadap produk domestik bruto Indonesia, dengan menggunakan variabel Jumlah wisatawan China, Rata-rata pengeluaran wisatawan China perkunjugan, Nilai tukar Yuan China, dan Produk domestik bruto China.
\end{abstract}

Kata Kunci : Jumlah Wisatawan, Rata-rata pengeluaran wisatawan perkunjungan, Nilai Tukar, Produk Domestik Bruto

\section{Pendahuluan}

Pariwisata merupakan salah satu penopang roda perekonomian di berbagai negara di dunia dan semakin lama semakin banyak dikembangkan oleh berbagai negara. Hal ini disadari karena pariwisata merupakan sektor yang dapat menyumbangkan pendapatan negara selain industri dan perdagangan. Hasil pendapatan dari sektor pariwisata dapat diandalkan dalam membantu kemajuan perekonomian sebuah negara, dapat dilihat pada tabel 1.1 di bawah, bahwa pendapatan sektor pariwisata menempati peringkat ke 4 pendapatan terbesar diIndonesia pada tahun 2014-2015.

Tabel 1.1 RANKING DEVISA TAHUN 2014-2015

\begin{tabular}{|c|l|r|l|r|}
\hline \multirow{2}{*}{ Rank } & \multicolumn{2}{|c|}{2014} & \multicolumn{2}{c|}{2015} \\
\cline { 2 - 5 } & Jenis Komoditas & $\begin{array}{c}\text { Nilai } \\
\text { (juta USD) }\end{array}$ & Jenis Komoditas & $\begin{array}{c}\text { Nilai } \\
\text { (juta } \\
\text { USD) }\end{array}$ \\
\hline $\mathbf{1}$ & Minyak \& gas bumi & $30,318.80$ & Minyak \& gas bumi & $18,552.10$ \\
\hline $\mathbf{2}$ & Batu bara & $20,819.30$ & Batu bara & $15,943.00$ \\
\hline $\mathbf{3}$ & Minyak kelapa sawit & $17,464.90$ & Minyak kelapa sawit & $15,385.20$ \\
\hline $\mathbf{4}$ & Pariwisata & $\mathbf{1 1 , 1 6 6 . 1 3}$ & Pariwisata & $\mathbf{1 2 , 2 2 5 . 8 9}$ \\
\hline $\mathbf{5}$ & Pakaian jadi & $7,450.90$ & Pakaian jadi & $7,371.90$ \\
\hline
\end{tabular}

Sumber : Kemenpar 2015 
Berdasarkan tabel diatas dapat dilihat bahwa kegiatan kepariwisataan di Indonesia tahun-tahun terakhir ini semakin meningkat. Dalam jangka panjang, dimana sektor pariwisata diharapkan menjadi sektor yang mampu memimpin dalam pembangunan, maka pengkajian yang lebih intensif dan menyeluruh perlu dilakukan rnengingat sektorsektor pembangunan lainnya yang secara langsung maupun tidak langsung besar pengaruhnya dalam pengembangan pariwisata.

Pada kegiatan perdagangan internasional, valuta asing berperan sebagai alat pembayaran dalam perdagangan internasional. Dengan menggunakan valuta asing, setiap negara yang ada di seluruh penjuru dunia dapat dengan mudah melakukan aktivitas jual beli tanpa harus terkendala masalah penggunaan mata uang. Perdagangan internasional dan valuta asing menjadi indikator untuk mengukur Produk Domestik Bruto pada suatu negara. Produk Domestik Bruto (PDB) sering dianggap sebagai ukuran terbaik dari kinerja perekonomian suatu negara. PDB sebagai nilai pasar semua barang dan jasa akhir yang diproduksi dalam suatu perekonomian selama kurun waktu tertentu.

Keberhasilan pengembangan sektor pariwisata berarti akan berdampak terhadap banyak aspek yang diantaranya meningkatkan devisa dari sektor pariwsata, yang dapat diukur melalui jumlah wisatawan asing dan pengeluaran rata rata wisatawan per kunjugan, dimana hal tersebut berbanding lurus dengan konsumsi dalam suatu negara. Dengan meningkatnya konsumsi, maka meningkat pula kebutuhan atas mata uang yang beredar pada negara tersebut.

Pada tahun 2016 Indonesia memiliki 11.519.275 wisatawan asing dari berbagai macam negara. Jumlah tersebut mengalami peningkatan sebesar $13 \%$ dari tahun sebelumnya yaitu 10.230.775. China menjadi salah satu negara yang menjadi penyumbang wisatawan terbanyak pada tahun 2016 dengan menyumbang $13,51 \%$ dari total wisatawan yang datang ke Indonesia. 


\section{Landasan Teori}

Dalam penelitian ini menggunakan empat variabel bebas yaitu Jumlah Wisatawan, Rata-rata Pengeluaran Wisatawan Perkunjungan, Nilai Tukar, Produk Domestik Bruto.

\section{- Jumlah wisatawan}

Jumlah wisatawan adalah jumlah seseorang melakukan perjalanan ke negara lain selain negara atau diluar tempat kediamannya dengan tujuan utama kunjungan selain alasan untuk melakukan melakukan kegiatan yang menghasilkan upah

\section{- Rata-rata Pengeluaran Wisatawan Perkunjungan}

Rata-rata pengeluaran wisatawan perkunjungan menurut BPS adalah Banyaknya uang yang dibelanjakan oleh seorang wisatawan mancanegara selama berada di Indonesia dalam satu hari dan dalam satu kali kunjungan.

\section{- Nilai Tukar}

Menurut Mahyus Ekananda (2014:168) nilai tukar adalah harga suatu mata uang relatif terhadap mata uang negara lain. Kurs memainkan peranan penting dalam keputusan-keputusan pembelanjaan, karena kurs memungkinkan kita menerjemahkan hargaharga dari berbagai negara ke dalam satu bahasa yang sama.

\section{- Produk Domestik Bruto}

Menurut Bank Indonesia Produk Domestik Bruto (PDB) merupakan salah satu indikator penting untuk mengetahui perkembangan perekonomian di suatu negara dalam suatu periode tertentu, baik atas dasar harga berlaku maupun atas dasar harga konstan. PDB pada dasarnya merupakan jumlah nilai tambah yang dihasilkan oleh seluruh unit usaha di suatu negara tertentu dalam periode tertentu. Jumlah nilai barang dan jasa akhir yang disediakan dari produksi harus sama dengan nilai barang yang digunakan. 


\section{Metodologi}

\section{- Jenis \& Sumber Data}

Data yang digunakan oleh penulis pada penelitian kali ini adalah data sekunder. Data sekunder adalah data yang dioeroleh penulis dari pihak lain, dalam bentuk literatur, studi pustaka, atau penelitian sejenis sebelumnya yang berkaitan dengan penelitian kali ini. Data sekunder dalam penelitian ini bersumber dari Badan Pusat Statistik (BPS), Kementrian Pariwisata RI, World Bank dan literatur-literatur lainnya seperti buku dan jurnal. Data yang di gunakan adalah data deret waktu (time series) 2007-2016 dan data deret lintang (cross section).

\section{- Objek Penelitian}

Objek yang digunakan dalam penelitian ini adalah Wisatawan Negara China. Adapun variabel yang digunakan dalam penelitian ini adalah variabel jumlah wisatawan negara China (X1), rata-rata pengeluaran wisatawan China perkunjugan (X2), Nilai tukar Yuan China terhadap Rupiah Indonesia (X3), PDB Negara China (X4), dan PDB Negara Indonesia (Y).

\section{- Analisis Data}

Untuk menguji hipotesis dalam penelitian ini, peneliti menggunakan analisis statistik yaitu metode regresi lenier berganda. Model analisis data yang digunakan dalam penelitian ini adalah dengan menggunakan angka-angka, rumus atau model matematis untuk mengetahui apakah ada pengaruh signifikas terhadap variabel Jumlah wisatawan negara China (X1), Rata-rata pengeluaran wisatawan China perhari perkunjugan (X2), Nilai tukar Yuan China terhadap Rupiah Indonesia (X3), Produk domestik bruto negara China (X4), terhadap Produk domestik bruto Indonesia (Y) pada tahun 2012-2016. 


\section{Hasil Penelitian}

\section{Uji Asumsi Klasik}

\section{Uji Multikoleniaritas}

Hasil perhitungan nilai Tolerance tidak ada variabel independen yang memiliki nilai Tolerance kurang dari 0.10 dengan nilai Tolerance masing-masing variabel independen bernilai X1 sebesar 0.150, X2 sebesar 0.593, X3 sebesar 0.197, dan X4 sebesar 0,155.

\section{Tabel 4.6 Hasil Uji Multikoleniaritas}

\begin{tabular}{|c|c|c|c|c|c|c|c|c|}
\hline & & \multicolumn{2}{|c|}{ Unstandardized Coefficients } & \multirow{2}{*}{$\begin{array}{c}\begin{array}{c}\text { Standardized } \\
\text { Coefficients }\end{array} \\
\text { Beta }\end{array}$} & \multirow[b]{2}{*}{$t$} & \multirow[b]{2}{*}{ Sig. } & \multicolumn{2}{|c|}{ Collinearity Statistics } \\
\hline \multicolumn{2}{|c|}{ Model } & $B$ & Std. Error & & & & Tolerance & VIF \\
\hline \multirow[t]{5}{*}{1} & (Constant) & $2,930 E+11$ & 49688268181 & & 5,897 & .000 & & \\
\hline & $\mathrm{X} 1$ & 435919,124 & 102491,848 & 836 & 4,253 &, 000 &, 150 & 6,660 \\
\hline & $\times 2$ & $-84178940,39$ & 50854121,45 &,- 164 & $-1,655$ & , 107 & .593 & 1,686 \\
\hline & $\times 3$ & $-138558293,1$ & 29553442,92 &,- 805 & $-4,688$ & .000 & ,197 & 5,081 \\
\hline & $\times 4$ & .064 & .016 &, 783 & 4,049 & .000 & 155 & 6,447 \\
\hline
\end{tabular}

Merujuk hasil perhitungan nilai Tolerance dapat disimpulkan bahwa tidak ada multikolinieritas antar variabel independen dalam model regresi.

\section{Uji Heteroskedastisitas}

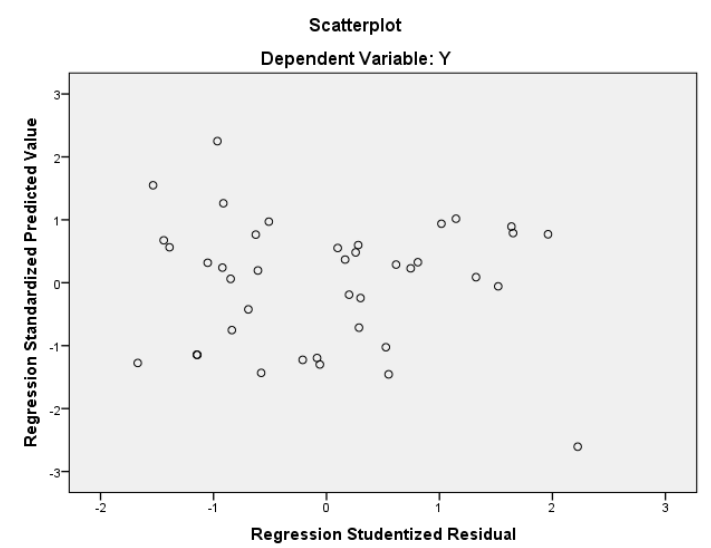

Gambar 4.6 Hasil Uji Heteroskedastisitas 
Berdasarkan gambar di atas terlihat bahwa tidak ada pola yang jelas serta titik-titik tersebut menyebar di atas dan di bawah angka 0 pada sumbu $\mathrm{Y}$. Hal ini menunjukkan bahwa data dalam penelitian ini tidak terjadi heteroskedastisitas.

\section{Uji Auto Korelasi}

\section{Tabel 4.7 Hasil Uji Auto Korelasi}

\begin{tabular}{|c|c|c|c|c|c|c|}
\hline \multicolumn{7}{|c|}{ Model Summary ${ }^{b}$} \\
\hline & \multicolumn{5}{|c|}{ Change Statistics } & \multirow[b]{2}{*}{$\begin{array}{l}\text { Durbin- } \\
\text { Watson }\end{array}$} \\
\hline Model & $\begin{array}{c}\text { R Square } \\
\text { Change }\end{array}$ & F Change & df1 & df2 & Sig. F Change & \\
\hline 1 &, $797^{\mathrm{a}}$ & 34,313 & 4 & 35 &, 000 & 1,759 \\
\hline
\end{tabular}

a. Predictors: (Constant), X4, X2, X3, X1

b. Dependent Variable: $Y$

Berdasarkan tabel 4.7 di atas nilai Durbin Watson sebesar 1.759, pembanding menggunakan nilai signifikansi 5\%, jumlah sampel $40(\mathrm{n})$, dan jumlah variabel independen $4(\mathrm{k}=4)$, maka di tabel DurbinWatson akan didapat nilai du sebesar 1,720. Karena nilai DW 1,759 lebih besar dari batas atas (du) 1,72 dan kurang dari 4 - 1.72 (2.28), maka dapat disimpulkan bahwa tidak terdapat autokorelasi.

\section{Uji Hipotesis}

Analisis yang digunakan untuk menguji hipotesis dalam penelitian ini adalah analisis regresi linear berganda.

\section{Tabel 4.8 Hasil Uji Hipotesis}

\begin{tabular}{|c|c|c|c|c|c|c|c|c|}
\hline & & \multicolumn{2}{|c|}{ Unstandardized Coefficients } & \multirow{2}{*}{$\begin{array}{c}\begin{array}{c}\text { Standardized } \\
\text { Coefficients }\end{array} \\
\text { Beta }\end{array}$} & \multirow[b]{2}{*}{$t$} & \multirow[b]{2}{*}{ Sig. } & \multicolumn{2}{|c|}{ Collinearity Statistics } \\
\hline \multicolumn{2}{|c|}{ Model } & $\mathrm{B}$ & Std. Error & & & & Tolerance & VIF \\
\hline \multirow[t]{5}{*}{1} & (Constant) & $2,930 \mathrm{E}+11$ & 49688268181 & & 5,897 &, 000 & & \\
\hline & $\mathrm{X} 1$ & 435919,124 & 102491,848 & 836 & 4,253 &, 000 &, 150 & 6,660 \\
\hline & $\mathrm{X} 2$ & $-84178940,39$ & 50854121,45 &,- 164 & $-1,655$ &, 107 &, 593 & 1,686 \\
\hline & $\mathrm{X} 3$ & $-138558293,1$ & 29553442,92 &,- 805 & $-4,688$ &, 000 & ,197 & 5,081 \\
\hline & $\mathrm{X} 4$ & 064 &, 016 &, 783 & 4,049 &, 000 & 155 & 6,447 \\
\hline
\end{tabular}

a. Dependent Variable: $Y$ 
Berdasarkan tabel diatas, persamaan regresi linier berganda pada penelitian ini adalah sebagai berikut :

$$
\mathrm{Y}=2,930 \mathrm{E}+11+435919,124 \mathrm{X} 1-84178940,39 \mathrm{X} 2-138558293,1 \mathrm{X} 3+0,064 \mathrm{X} 4+\mathrm{e}
$$

Persamaan regresi diatas dapat dijelaskan sebagai berikut:

a) Konstanta sebesar 2,930 artinya jika tidak ada pengaruh $\mathrm{X} 1, \mathrm{X} 2$, X3 dan X4 terhadap Y, maka nilai Y sebesar 2,930E+11.

b) Variabel X1 mempunyai nilai 435919,124 artinya bahwa setiap terjadi kenaikan X1 sebesar 1, maka $\mathrm{Y}$ akan mengalami peningkatan sebesar 435919,124. Dengan asumsi variabel lain tetap.

c) Variabel X2 mempunyai nilai 84178940,39 artinya bahwa setiap terjadi kenaikan X2 sebesar 1, maka Y akan mengalami penurunan sebesar 84178940,39. Dengan asumsi variabel lain tetap.

d) Variabel X3 mempunyai nilai 138558293,1 artinya bahwa setiap terjadi kenaikan X3 sebesar 1, maka Y akan mengalami penurunan sebesar 138558293,1. Dengan asumsi variabel lain tetap.

e) Variabel X4 mempunyai nilai 0,064 artinya bahwa setiap terjadi kenaikan $\mathrm{X} 4$ sebesar 1\%, maka $\mathrm{Y}$ akan mengalami peningkatan sebesar $6,4 \%$. Dengan asumsi variabel lain tetap. 


\section{Uji Koefisien Determinasi (R2)}

Uji Koefisien Determinasi bertujuan untuk mengukur sebesar besar kemampuan model dalam menerangkan variasi variabel dependen. Jika nilai R2 kecil berarti kemampuan variabel-variabel independen dalam menjelaskan variasi variabel dependen menjadi sangat terbatas.

Tabel 4.9 Hasil Uji Koefisien Determinasi

Model Summary
\begin{tabular}{|l|c|r|c|c|c|}
\hline Model & R & R Square & $\begin{array}{c}\text { Adjusted R } \\
\text { Square }\end{array}$ & $\begin{array}{c}\text { Std. Error of } \\
\text { the Estimate }\end{array}$ & $\begin{array}{c}\text { Durbin- } \\
\text { Watson }\end{array}$ \\
\hline 1 &, $893^{\text {a }}$ &, 797 &, 774 & 25984961070 & 1,759 \\
\hline
\end{tabular}
a. Predictors: (Constant), X4, X2, X3, X1
b. Dependent Variable: $Y$

Berdasarkan tabel 9, diperoleh nilai Adjusted R Square adalah 0.774 , hal ini berarti $77 \%$ variasi variabel terikat yaitu Y dapat dijelaskan oleh empat variasi variabel bebas yaitu X1, X2, X3, dan $\mathrm{X} 4$. Sedangkan sisanya $(100 \%-77 \%=23 \%)$ dijelaskan oleh variabel lain di luar penelitian.

\section{Uji Parsial (Uji t)}

\section{Tabel 4.10 Hasil Uji Parsial}

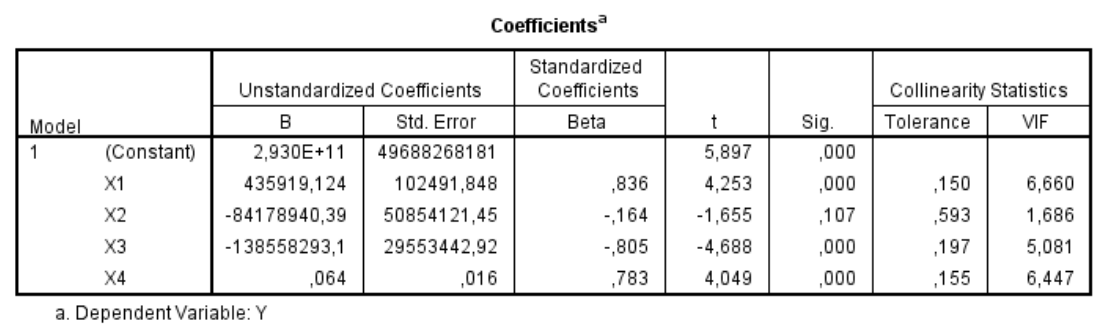


a) Jumlah wisatawan negara China (X1) memiliki nilai t 4,253 dengan nilai probabilitas signifikan sebesar 0,00. Signifikan t lebih kecil dari $\alpha(0,05)$, maka Ha diterima. Berarti terdapat pengaruh signifikan antara Jumlah wisatawan negara China terhadap Produk Domestik Bruto Indonesia.

b) Rata-rata pengeluaran wisatawan negara China perkunjungan (X2) memiliki nilai $\mathrm{t}-1,655$ dengan nilai probabilitas signifikan sebesar 0,107 . Signifikan t lebih besar dari $\alpha(0,05)$, maka H0 diterima. Berarti tidak terdapat pengaruh signifikan antara Rata-rata pengeluaran wisatawan negara China terhadap Produk Domestik Bruto Indonesia.

c) Nilai tukar Yuan China terhadap Rupiah Indonesia (X3) memiliki nilai $\mathrm{t}-4,688$ dengan nilai probabilitas signifikan sebesar 0,0 . Signifikan t lebih kecil dari $\alpha(0,05)$, maka Ha diterima. Berarti terdapat pengaruh signifikan antara Nilai tukar Yuan China terhadap Rupiah Indonesia terhadap Produk Domestik Bruto Indonesia.

d) Produk Domestik Bruto negara China (X4) memiliki nilai t 4,049 dengan nilai probabilitas signifikan sebesar 0,0. Signifikan t lebih kecil dari $\alpha(0,05)$, maka Ha diterima. Berarti terdapat pengaruh signifikan antara Produk Domestik Bruto negara China terhadap Produk Domestik Bruto Indonesia.

\section{Uji Simultan (Uji f)}

Uji $F$ bertujuan untuk mengetahui pengaruh variabel independen secara simultan terhadap variabel dependen.

\section{Tabel 4.11 Hasil Uji Simultan}

\begin{tabular}{|c|c|c|c|c|c|c|}
\hline \multicolumn{7}{|c|}{ ANOVA ${ }^{a}$} \\
\hline \multicolumn{2}{|c|}{ Model } & $\begin{array}{c}\text { Sum of } \\
\text { Squares }\end{array}$ & df & Mean Square & $\mathrm{F}$ & Sig. \\
\hline \multirow[t]{3}{*}{1} & Regression & $9,268 \mathrm{E}+22$ & 4 & $2,317 \mathrm{E}+22$ & 34,313 & $.000^{b}$ \\
\hline & Residual & $2,363 E+22$ & 35 & $6,752 \mathrm{E}+20$ & & \\
\hline & Total & $1,163 \mathrm{E}+23$ & 39 & & & \\
\hline
\end{tabular}


Dari tabel diatas, terlihat bahwa nilai signifikansi $\mathrm{F}=0,000$ (lebih kecil dari $\alpha=0,05$ ). Artinya Ha diterima. Dengan kata lain, Jumlah wisatawan negara China (X1), Rata-rata pengeluaran wisatawan negara China perkunjugan (X2), Nilai tukar Yuan China terhadap Rupiah Indonesia (X3), dan Produk domestik bruto negara China (X4) secara simultan berpengaruh secara signifikan terhadap Produk Domestik Bruto negara Indonesia.

\section{Pembahasan}

Dari hasil penelitian diatas, peneliti menggunakan model regresi linier berganda menggunakan Uji Simultan (Uji F) dimana memperoleh hasil nilai Probabilitas signifikasnsi sebesar 0,000 lebih kecil dari tingkat signifikansi 0,05 sehingga dapat diartikan bahwa jumlah wisatawan negara China, rata-rata pengeluaran wisatawan negara China perkunjungan, Nilai tukar Yuan China terhadap Rupiah Indonesia dan produk domestik bruto negara China terhadap variabel produk domestik bruto negara Indonesia. Dengan demikian dapat dipahami bahwa variabel X1 (jumlah wisatawan negara China) dan X2 (rata-rata pengeluaran wisatawan negara China perkunjungan), X3 (Nilai tukar Yuan China terhadap Rupiah Indonesia) secara bersama-sama memiliki pengaruh yang signifikan terhadap variabel $\mathrm{Y}$ (produk domestik bruto negara Indonesia) pada tahun 2007-2016. Selanjutnya dari analisis regresi linier berganda diperoleh nilai R Squared sebesar 0,774. Hasil ini menunjukan bahwa semua variabel bebas yaitu variabel jumlah wisatawan negara China, rata-rata pengeluaran wisatawan negara China perkunjungan, Nilai tukar Yuan China terhadap Rupiah Indonesia dan produk domestik bruto negara China mempunyai keeratan hubungan dengan variabel produk domestik bruto negara Indonesia memiliki kontribusi sebesar 77,4\%, sisanya dijelaskan oleh variabel lain yang tidak ada dalam penelitian. 
Kemudian pengaruh secara parsial yaitu untuk melihat pengaruh variabel jumlah wisatawan negara China, rata-rata pengeluaran wisatawan negara China perkunjungan, Nilai tukar Yuan China terhadap Rupiah Indonesia dan produk domestik bruto negara China terhadap produk domestik bruto negara Indonesia 2007-2016, yang akan diuraikan sebagai berikut:

\section{Pengaruh Jumlah Wisatawan Negara China terhadap Produk Domestik Bruto Indonesia}

Uji parsial (uji t) pada variabel Jumlah Wisatawan Negara China memiliki probabilitas signifikansi sebesar 0,00 yang berarti Jumlah Wisatawan Negara China memiliki pengaruh yang signifikan terhadap Produk Domestik Bruto Indonesia. Hal ini dibuktikan dengan data yang didapatkan bahwa negara china menyumbang wisatawan terbanyak pada tahun 2016 yaitu sebanyak 1.556 .771 atau sebesar $13,51 \%$ dari total wisatawan asing yang datang pada tahun 2016. Dengan banyaknya wisatawan yang berkunjung akan mengakibatkan konsumsi pada produk yang ditawarkan oleh lokasi tempat wisata. Hal tersebut akan meningkatkan Produk Domestik Bruto dengan pendekatan produksi.

\section{Pengaruh Rata-rata Pengeluaran Wisatawan Negara China Perkunjungan terhadap Produk Domestik Bruto Indonesia}

Uji parsial (uji t) pada variabel Rata-rata Pengeluaran Wisatawan Negara China Perkunjungan memiliki probabilitas signifikansi sebesar 0,107 yang berarti variabel Rata-rata Pengeluaran Wisatawan Negara China Perkunjungan tidak memiliki pengaruh yang signifikan terhadap Produk Domestik Bruto Indonesia. Hal ini dapat dibuktikan dengan data yang didapatkan bahwa rata-rata pengeluaran wisatawan negara china perkunjungan tidak sebanding dengan jumlah wisatawan yang diberikan. Pasalnya, rata-rata pengeluaran perkunjungan dari wisatawan china hanya sebesar 1.196,15 USD, masih dibawah rata-rata pada setiap negara sebesar 
1.201,04 USD. Hal ini membuat China berada di urutan 25 dari 38 negara wisatawan yang mengunjungi Indonesia.

\section{Pengaruh Nilai Tukar Yuan China terhadap Rupiah Indonesia terhadap Produk Domestik Bruto Indonesia}

Uji parsial (uji t) pada variabel Nilai Tukar Yuan China terhadap Rupiah Indonesia memiliki probabilitas signifikansi sebesar 0,00 yang berarti bahwa variabel Nilai tukar Yuan China terhadap Rupiah Indonesia memiliki pengaruh yang signifikan. Hubungan antara variabel ini adalah negatif yang berarti bahwa setiap terjadinya apresiasi dari nilai tukar Yuan China akan berdampak pada pengurangan Produk Domestik Bruto Indonesia. Karena China menjadi salah satu pengimpor Indonesia, maka setiap kenaikan atau apresiasi dari Yuan China akan mengakibatkan naiknya harga dari barang barang yang akan diimpor dari China. Kenaikan tersebut dapat mepengaruhi neraca perdagangan. Defisit neraca perdagangan akan menjadi pengurang dari nilai Produk Domestik Bruto.

\section{Pengaruh Produk Domestik Bruto China Terhadap Produk Domestik Bruto Indonesia}

Uji parsial (uji t) pada variabel Produk Domestik Bruto China memiliki probabilitas signifikansi sebesar 0,00 yang berarti bahwa variabel Produk Domestik Bruto China memiliki pengaruh yang signifikan terhadap Produk Domestik Bruto Indonesia. Hal tersebut dikarenakan China memiliki perekonomian terkuat ke-2 di dunia dan menjadi mitra dagang dari negara Indonesia. Penurunan atau peningkatan dari PDB milik negara China akan mempengaruhi negara negara yang menjadi mitra dagang dari negara China. Jika terjadi penurunan dari PDB milik negara China maka berarti bahwa berkurangnya produksi dan konsumsi yang dilakukan oleh negara China. Hal tersebut mengakibatkan tergoyangnya arus ekspor dan impor yang dilakukan oleh China. 


\section{DAFTAR PUSTAKA}

A.J, Mulyadi. 2012. Kepariwisataan dan Perjalanan, Jakarta: Raja Grafindo Persada.

Asriandi, Ian. 2016. Strategi Pengembangan Obyek Wisata Air Terjun Bissapu Di Kabupaten Bantaeng. Makassar: Jurnal. Universitas Hasanuddin.

Badan Pusat Statistik Jakarta Pusat, 2017. Statistik Kunjungan Wisatawan Mancanegara 2017. Jakarta Pusat : Badan Pusat Statistik.

Bank Dunia, World Bank Development Report 2016, Washington DC, USA.

Bank Indonesia, Kurs Transaksi tengan Yuan China, Jakarta : Available online at : www.bi.go.id

Ekananda, Mahyus. 2016. Analisis Ekonometrika Data Panel. Jakarta: Mitra Wacana Media.

Hasanah, Erni Umi dan Danang Sunyoto. Pengantar Ilmu Ekonomi Makro. Yogyakarta: CAPS, 2012

Ismayanti. 2010. Pengantar Pariwisata. Jakarta: PT Gramedia Widisarana Indonesia.

Joesoef, Soelaiman. 2008. Konsep Dasar Pendidikan Luar Sekolah. Jakarta: PT. Bumi Aksara.

Kementrian Pariwisata, R.I., 2016. Ranking Devisa Tahun 2014-2015, Jakarta : Pusat Data dan Informasi Kementrian Pariwisata.

Nanang Martono. 2010. Metode Penelitian Kuantitatif. Jakarta. Rajawali Pers

Rahardja, Prathama. Teori Ekonomi Mikro Suatu Pengantar. Lembaga Penerbit Fakultas Ekonomi Universitas Indonesia, 2018.

Sadono, Sukirno. 2010. Makroekonomi. Teori Pengantar. Edisi Ketiga. PT. Raja Grasindo Perseda. Jakarta.

Samuelson, Paul A dan Nordhaus, William D,2004, Ilmi Makro Ekonomi.Jakarta PT. Media Edukasi

Seherman Rosyidi, Pengantar Teori Ekonomi Pendekatan kepada Teori Ekonomi Mikro dan Makro, Jakarta : PT Raja Grafindo Persada, 2012 
Sugiama, A. Gima. "Ecotourism: Pengembangan Pariwisata berbasis konservasi alam." Bandung, Guardaya Intimarta 17 (2011)

Sugiyono. 2011. Metode Penelitian Kuantitatif, Kualitatif dan R\&D. Bandung : Afabeta.

Sukardi. (2008). Metodologi Penelitian Pendidikan, Kompetensi dan Praktiknya. Jakarta : PT. Bumi Aksara.

Supriyati. 2012. Metodologi Penelitian Komputerisasi Akuntansi. Bandung: LABKAT.

Suwantoro, Gamal. 2004. Dasar-dasar Pariwisata. Penerbit Andi Yogyakarta 